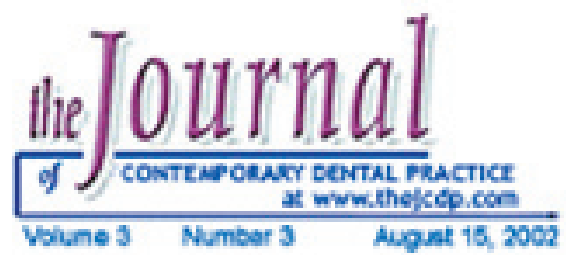

\title{
The Effect of Salvadora Persica Extract (Miswak) and Chlorahexidine Gluconate on Human Dentin: A SEM Study
}

\section{Khalid AImas, BDS, MSc, DDPH, FRACDS, FDSRCS, FICD, FADI}

\begin{abstract}
Bacterial plaque is solely responsible for the initiation and progression of periodontal diseases. There are different mechanical and chemical methods available for the maintenance of oral health through plaque control. Toothbrushes and miswak (chewing sticks) are widely used for the mechanical removal of plaque. Chlorhexidine gluconate $(\mathrm{CHX})$ is one of the best-proven anti-plaque agents.

The aim of this study was to evaluate the effects of $\mathrm{CHX}$ and miswak extract on healthy and periodontally involved human dentin. Sixteen human premolars recently extracted for orthodontic and periodontal reasons were used in the study. Teeth were free from caries, cervical restorations, or erosions. The dentin disc specimens were prepared and half of them were etched with $6 \%$ citric acid for $120 \mathrm{sec}$. Both etched and unetched were further treated with $\mathrm{CHX}$ and 50\% miswak extract and prepared for Scanning Electron Microscopic (SEM) examination. It was concluded that $\mathrm{CHX} 0.2 \%$ and miswak extract $50 \%$ had a similar effect on dentin in the control group. Miswak extract removed more smear layer as compared to $\mathrm{CHX}$. Further research is needed in vivo to compare the effects of $\mathrm{CHX}$ and miswak extract on periodontally involved teeth and teeth with dentinal hypersensitivity.
\end{abstract}

Keywords: Chlorhexidine gluconate, $\mathrm{CHX}$, miswak extract, SEM, human dentin, periodontally involved dentin

Citation: Almas K.. The Effect of Salvadora Persica Extract (Miswak) and Chlorhexidine Gluconate on Human Dentin: A SEM Study. J Contemp Dent Pract 2002 August;(3)3: 027-035.

(C) Seer Publishing 


\section{Introduction}

Bacterial plaque is the primary etiology but not solely responsible for the initiation and progression of periodontal diseases. There are different methods available for the maintenance of oral health. These are mainly mechanical and chemical. Toothbrushes and dentifrices are widely used for cleaning the teeth. The traditional toothbrush or chewing stick called "Miswak" has been used since ancient history.

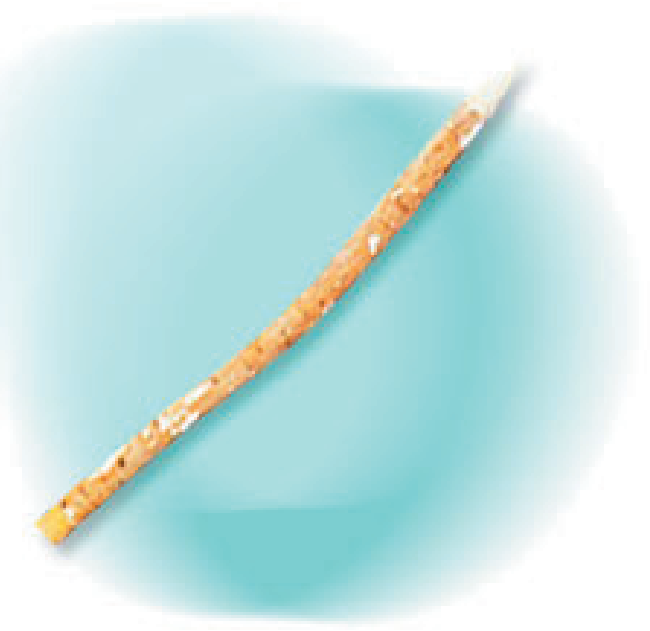

Miswak (chewing sticks) were used by the Babylonians some 7000 years ago; they were later used throughout the Greek and Roman empires and have been used by Jews, Egyptians, and in the Islamic empires. It is believed that this precursor to the modern day toothbrush was used in Europe until about 300 years ago. ${ }^{2}$ Today, miswak is being used in Africa, South America, Asia, the Middle East including Saudi Arabia, and throughout the Islamic countries. ${ }^{3}$ It has different names in different societies, for instance, miswak, siwak, or arak are used in the Middle East; miswak in Tanzania; datan and miswak in India and Pakistan. ${ }^{1}$ The use of the chewing stick is deeply rooted in many cultures. In the Middle East, the most common source of chewing sticks is the Arak (Salvadora persica) tree. In West Africa the lime tree (citrus aurantafolia) and the orange tree (Citrus sinesis) are used. The roots of Senna (Cassia vinnea) were used by black Americans and those of African laburnum (Cassia sieberianba) were used in Sierra Leone. Neem (Azadirachta indica) is widely used in the Indian subcontinent. ${ }^{4}$
Many studies have demonstrated the antibacterial, anti-caries, anti-periopathic, and anti-fungal properties of aqueous extracts of various chewing sticks. ${ }^{5,6,7,8}$ There are only three studies comparing the antimicrobial effects due to the age of the miswak. ${ }^{9,10,11}$ The relative accessibility and popularity of chewing sticks in the Middle East and Africa as an oral hygiene tool make it a cost effective agent for plaque control in such communities. $^{12,13}$

Chlorhexidine gluconate ( $\mathrm{CHX}$ ), a cationic bisbiguanide, is the best-known and most widely used member of the bisbiguanide class. The efficacy of $\mathrm{CHX}$ in significantly reducing plaque and gingivitis (compared with placebos) when used twice daily as a supplement to tooth brushing is well established. The mechanism of action of $\mathrm{CHX}$ is due mainly to the rupture of the bacterial cell wall and precipitation of the cytoplasmic content.

Early studies used $10 \mathrm{ml}$ of a $0.2 \%$ solution for a total of $20 \mathrm{mg} \mathrm{CHX}$ per use. There are studies supporting the effectiveness of $0.12 \% \mathrm{CHX}$ using $15 \mathrm{ml}$ of this solution. ${ }^{15,16,17}$ The total amount of $\mathrm{CHX}$ per use was essentially the same, and the clinical findings with the two formulations were similar: plaque reductions in the $50-55 \%$ range and reduction in gingivitis of about $45 \%$. The major side effects of $\mathrm{CHX}$ are a brown staining of the teeth and tongue, formation of supragingival calculus, taste alteration, and oral desquamation in children. ${ }^{18,19,16,20}$ Allergic reactions have been reported in some patients, especially Asians. ${ }^{21}$

When $\mathrm{CHX}$ is used following brushing, one should allow at least 30 minutes after tooth brushing and before rinsing with this chemical because of an

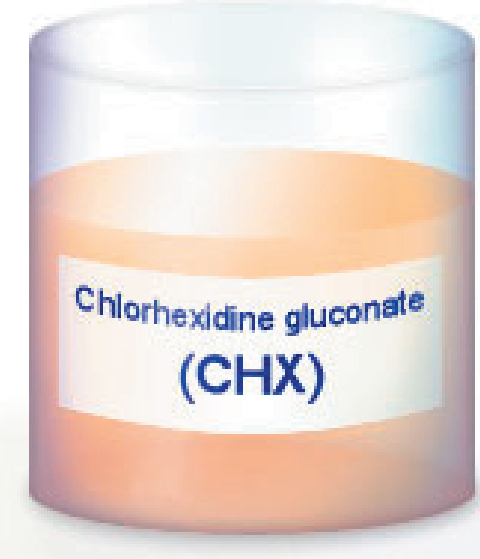


interaction (and possible activation) between various positively charged dentifrice detergents and the cationic $\mathrm{CHX} .^{22}$ Also, an antagonistic interaction can occur with the anionic fluoride ion in mouthrinses, toothpastes, and stannous fluoride products. The 30-minute interval is intended to minimize the diminution in activity of $\mathrm{CHX}{ }^{21}$

To date, there are no studies comparing miswak extract and $\mathrm{CHX}$ solution on the dentinal root surface. The aim of this study was to compare the dentin surface changes after the application of $50 \%$ aqueous extract of miswak (Salvadora persica) and $0.2 \% \mathrm{CHX}$ on etched and unetched healthy and periodontally involved dentin.

\section{Materials and Methods}

\section{Study Design}

Sixteen human premolars recently extracted for orthodontic (eight) and periodontic reasons (eight) were used in the study. Teeth were free from caries, cervical restorations, or erosions and were stored in tubes containing saline. The anatomical crown (including $1 \mathrm{~mm}$ of the coronal portion of the root) was removed with a water coolant high-speed bur. To remove the cementum and expose the underlying dentin, the root surface was thoroughly planed and flattened with a $15 \mathrm{~mm}$ grit diamond (Perioset, Intensive Philadelphia, PA) used under continuous water coolant at 20,000 to $30,000 \mathrm{rpm}$. The root was then sectioned mesiodistally to obtain a $1 \mathrm{~mm}$ thick dentin disc.

(Figure 1)

\section{Treatment}

The dentin disc was divided into two halves, etched and unetched groups. One half of the etched half disc was rotated in $6 \%$ citric acid for $120 \mathrm{sec}$ and then quartered. Control and test quarters were prepared accordingly. (Figure 1)

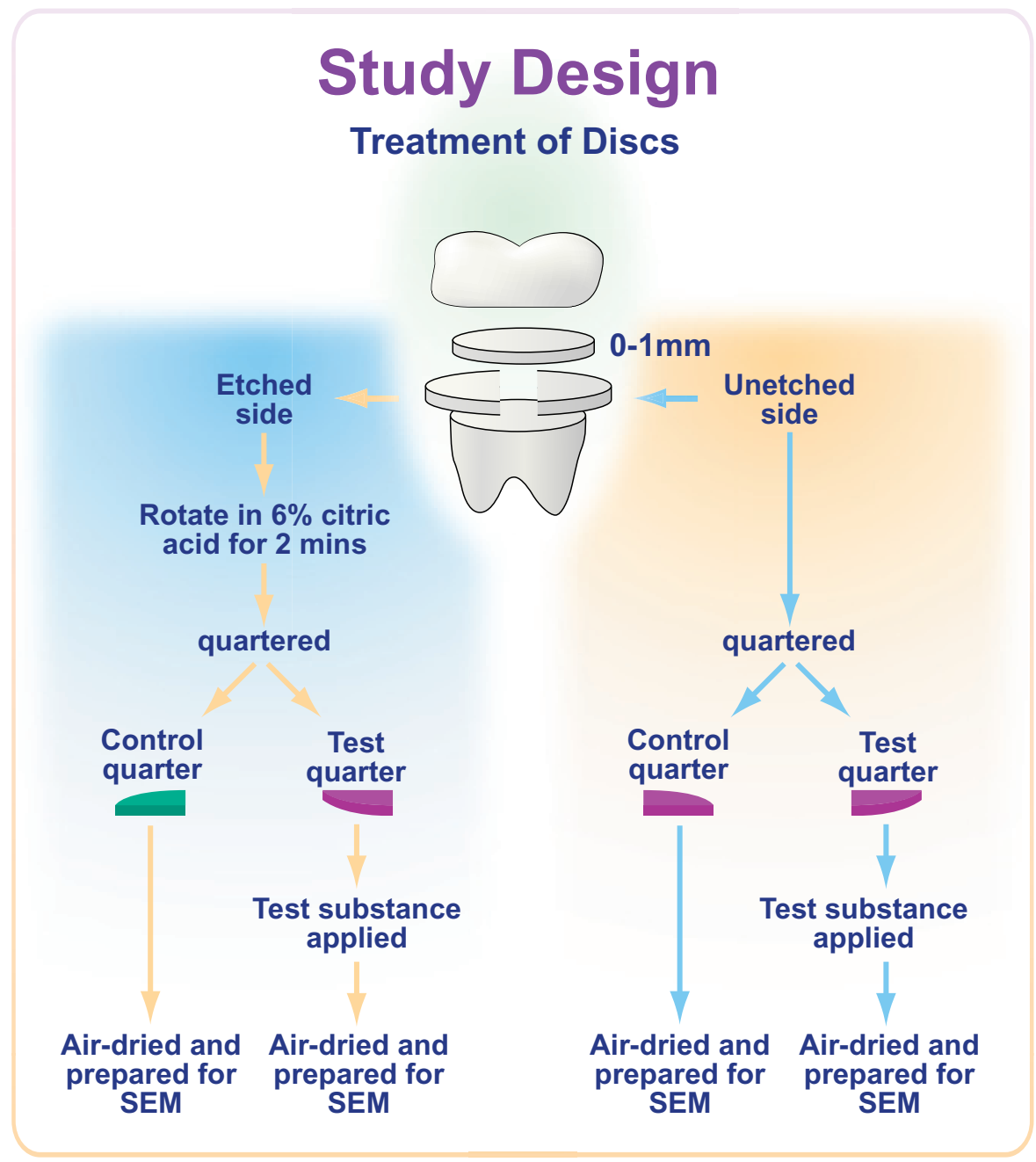


Table 1. Treatment modalities of the root dentin.

\begin{tabular}{|c|c|c|c|c|c|c|c|}
\hline Group & Specimens & Citric Acid Etched pH 2.5 & Test Material & pH & Quantity & Duration (sec) & No. \\
\hline 1 & $\begin{array}{l}\text { Healthy } \\
\text { (Control) }\end{array}$ & $\begin{array}{l}\text { Etched } \\
\text { Unetched }\end{array}$ & - & 2.5 & $5 \mathrm{ml}$ & 120 & $\begin{array}{l}4 \\
4\end{array}$ \\
\hline 2 & $\begin{array}{l}\text { Periodoentally Irwolved } \\
\text { (Control) }\end{array}$ & $\begin{array}{l}\text { Etched } \\
\text { Unetched }\end{array}$ & - & 2.5 & $5 \mathrm{ml}$ & 120 & $\begin{array}{l}4 \\
4\end{array}$ \\
\hline 3 & $\begin{array}{l}\text { Healthy } \\
\text { (Experimental) }\end{array}$ & $\begin{array}{l}\text { Etched } \\
\text { Unetched }\end{array}$ & $\begin{array}{l}\mathrm{CHX} \\
\mathrm{CHX}\end{array}$ & 6.1 & $5 \mathrm{ml}$ & 120 & $\begin{array}{l}4 \\
4\end{array}$ \\
\hline 4 & $\begin{array}{l}\text { Periodoentally involved } \\
\text { (Experimental) }\end{array}$ & $\begin{array}{l}\text { Etched } \\
\text { Unetched }\end{array}$ & $\begin{array}{l}\mathrm{CHX} \\
\mathrm{CHX}\end{array}$ & 6.1 & $5 \mathrm{ml}$ & 120 & $\begin{array}{l}4 \\
4\end{array}$ \\
\hline 5 & $\begin{array}{l}\text { Healthy } \\
\text { (Experimental) }\end{array}$ & $\begin{array}{l}\text { Etched } \\
\text { Unetched }\end{array}$ & $\begin{array}{l}\text { Miswak } \\
\text { Miswak }\end{array}$ & 6.0 & $5 \mathrm{ml}$ & 120 & $\begin{array}{l}4 \\
4\end{array}$ \\
\hline 6 & $\begin{array}{l}\text { Periodontally Irwolved } \\
\text { (Experimental) }\end{array}$ & $\begin{array}{l}\text { Etched } \\
\text { Unetched }\end{array}$ & $\begin{array}{l}\text { Miswak } \\
\text { Miswak }\end{array}$ & 6.0 & $5 \mathrm{ml}$ & 120 & $\begin{array}{l}4 \\
4\end{array}$ \\
\hline
\end{tabular}

The dentin specimens were etched and unetched. They were etched with $6 \%$ citric acid $(\mathrm{pH} 2.5)$. Following etching, $\mathrm{CHX} 0.2 \%(\mathrm{pH} 6.1)$ or $50 \%$ aqueous extract of miswak ( $\mathrm{pH}$ 6.0) were used. The $\mathrm{pH}$ of each solution (citric acid, $\mathrm{CHX}$, and miswak extract) was tested with a hand-held, battery operated pH meter (Model 594100 Cole Parmer Instrument Company, Chicago, IL). A total of 48 specimens were obtained and prepared as per study design. The 48 dentin specimens were divided into 6 groups of healthy and periodontally involved discs of 8 specimens each. (Table 1)

\section{SEM Preparation}

All specimens were fixed in glutaraldehyde $(\mathrm{pH}$ 7.3) and then prepared for Scanning Electron Microscopy (SEM) after fixation; dehydration was done in a graded series of ethanol and with 100\% acetone use as a final step. Each of the specimens was mounted on aluminum stubs coated in gold with a sputter technique. The specimens were examined by the SEM (SEM, Jeol, Japan) operated at $25 \mathrm{KV}$ and with a tilt angle of between 0-30 degrees. Twelve micrographs were prepared, one from each subgroup of 4 specimens.
Results

The appearance of each of the specimens within a conditioning regimen were similar. The results are presented in Table 2.

\section{Control Group}

1. More dentinal tubules are open in periodontally involved dentin as compared to healthy dentin in both etched and unetched specimens. (Figures 2, 3, 4, 5)

Healthy vs Periodontally Diseased Dentin

2. CHX and miswak solutions have a similar effect on healthy dentin. (Figures 6, 8, 10, 12)

3. Miswak opened more dentinal tubules in periodontally involved dentin. (Figure 11)

\section{CHX vs Miswak Extract}

4. CHX partially occluded dentinal tubules in both etched specimens. (Figures 6, 7)

5. Miswak extract opened more dentinal tubules in healthy etched and periodontally involved etched specimens. (Figures 10, 11) 
Table 2. Effects of CHX and miswak extract on root dentin.

\begin{tabular}{|c|c|c|c|c|c|c|}
\hline \multirow{3}{*}{ Dentin Specimen } & \multirow{2}{*}{\multicolumn{2}{|c|}{ Control Group Citric Acid }} & \multicolumn{4}{|c|}{ Experimental Group } \\
\hline & & & \multicolumn{2}{|c|}{$\mathrm{CHX}$} & \multicolumn{2}{|c|}{ Miswak } \\
\hline & $\mathrm{E}$ & UE & $\mathrm{E}$ & UE & E & UE \\
\hline Healthy & $\begin{array}{c}\text { SL } \\
\text { PODT } \\
\text { GD } \\
\text { C }\end{array}$ & $\begin{array}{l}\text { SL } \\
\text { GD }\end{array}$ & $\begin{array}{c}\text { SL } \\
\text { GD } \\
\text { DTO }\end{array}$ & $\begin{array}{l}S L \\
\text { GD }\end{array}$ & $\begin{array}{c}\text { GD } \\
\text { ODT } \\
\text { DTPO }\end{array}$ & $\begin{array}{c}\text { GD } \\
\text { PODT } \\
\text { ODT }\end{array}$ \\
\hline Periodontally Involved & $\begin{array}{c}\text { ODT } \\
\text { PODT } \\
\text { GD }\end{array}$ & $\begin{array}{c}\text { ODT } \\
\text { PODT } \\
\text { DTPO } \\
\text { GD }\end{array}$ & $\begin{array}{c}\text { ODT } \\
\text { PODT } \\
\text { DTO }\end{array}$ & $\begin{array}{l}S L \\
\text { GD }\end{array}$ & $\begin{array}{c}\text { GD } \\
\text { PODT } \\
\text { ODT }\end{array}$ & $\begin{array}{l}\text { DTO } \\
\text { GD }\end{array}$ \\
\hline
\end{tabular}

Key:

$\mathrm{E}=$ Etched

UE $=$ Unetched

$\mathrm{C}=$ Cracks

$\mathrm{GD}=$ Grinding debris

$\mathrm{SL}=$ Smear layer

ODT $=$ Opened dentinal tubules

PODT $=$ Partially opened dentinal tubules

DTO = Dentinal tubules occluded

DTPO = Dentinal tubules partially occluded

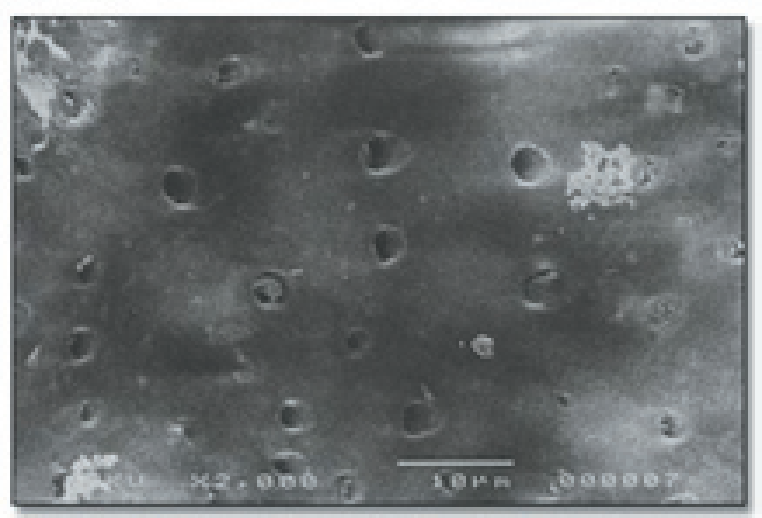

Figere 3: SEM photomicrograph of dentin surface shows opened dentinal tubeles, partially opened dentinal tubeles, and grinding debris. (Periodontally imvolved etched)

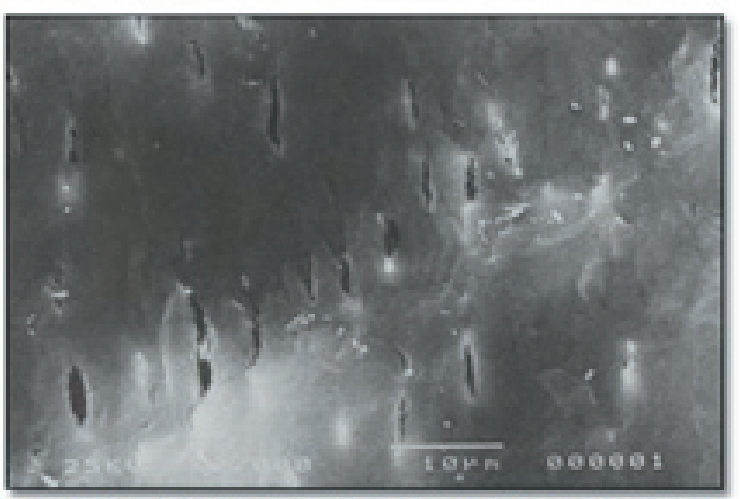

Figure 2: SEM phedemicrograph of dentin surfoce shows smeat layer, partially opened dentinal tubules, grinding debris, and some cracks. (Mealthy etched)

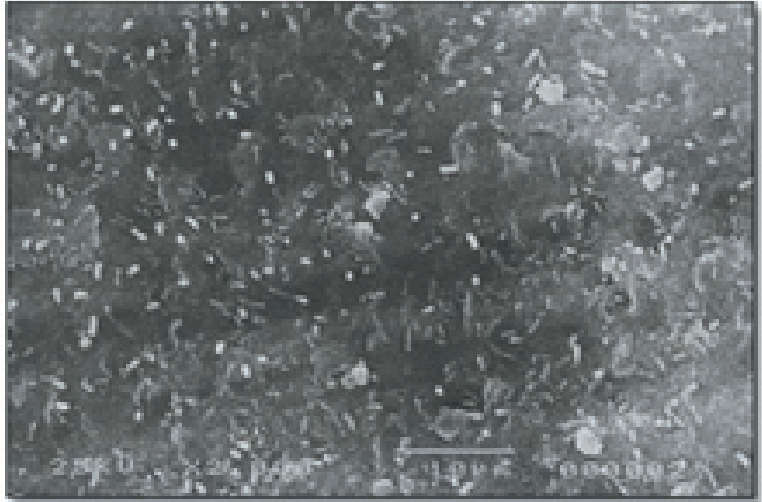

Figure 4: SEM phetomicrograph of dentin serfoce shows smeat layer and some grinding debris. (Healthy eneteched) 


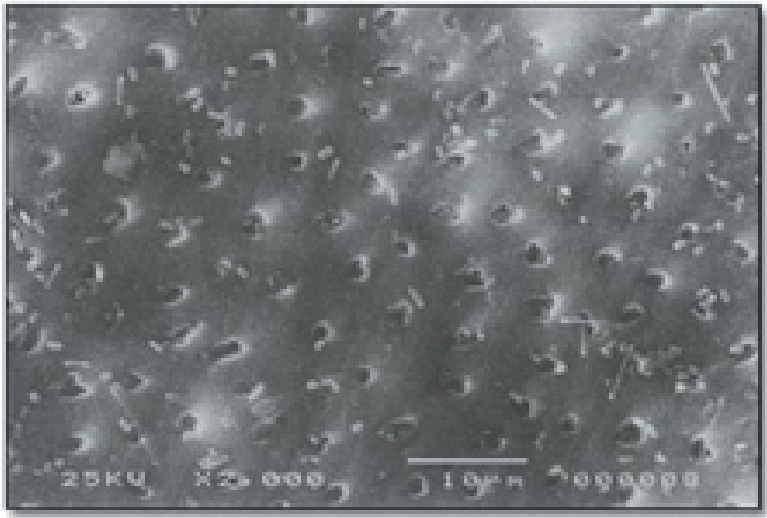

Figure 5: SEM photomicrograph of dentin surface shows opened dentinal tubules, partially opened dentinal tubules, dentinal tubules partially occluded, and some dentinal tubules occluded as well. (Periodontally involwed unetched)

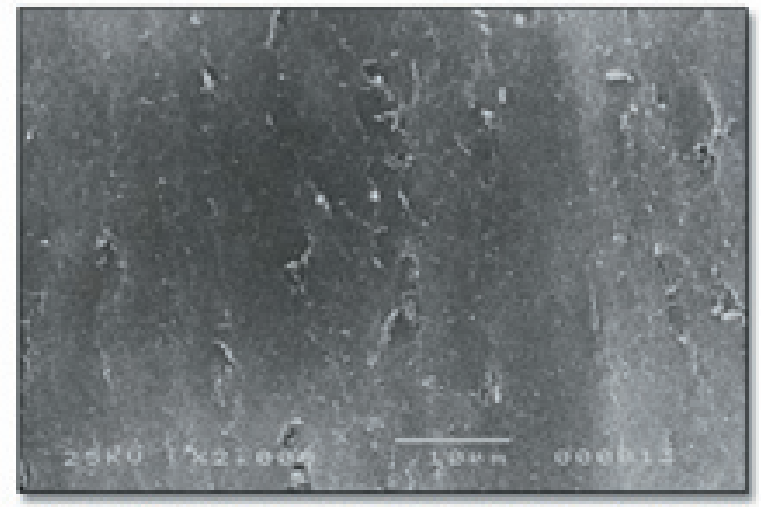

Figure 6: SEM photomicrograph of dentin surface shows smear layer, grinding debris, and dentinal tubules occluded. (Alealthy etched and $\mathrm{CHX}$

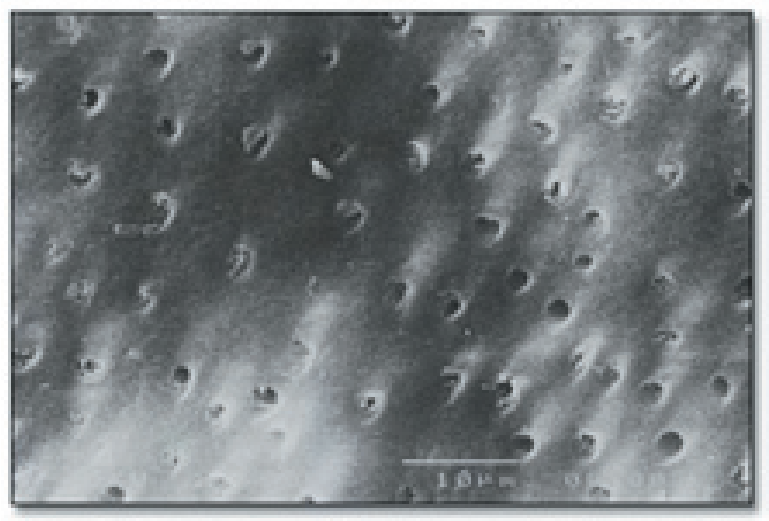

Figure 7: SEM photomicregraph of dentin surface shows

opened dentinal tubules, partially opened dentinal tubules, and some dentinal tubules occladed. Periodontally imvolved etched and $\mathrm{CHX}$

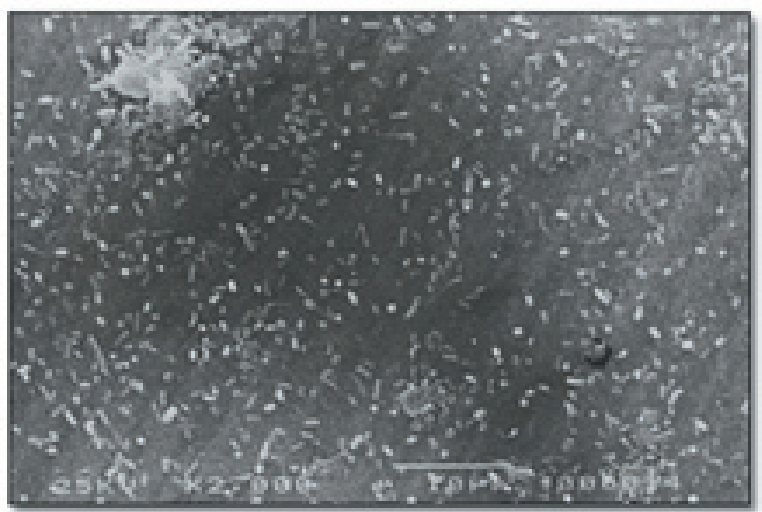

Figure 8: SEM photomicregraph of dentin surface shows smear layer and grinding sebris. (Healthy unetched and CHX?

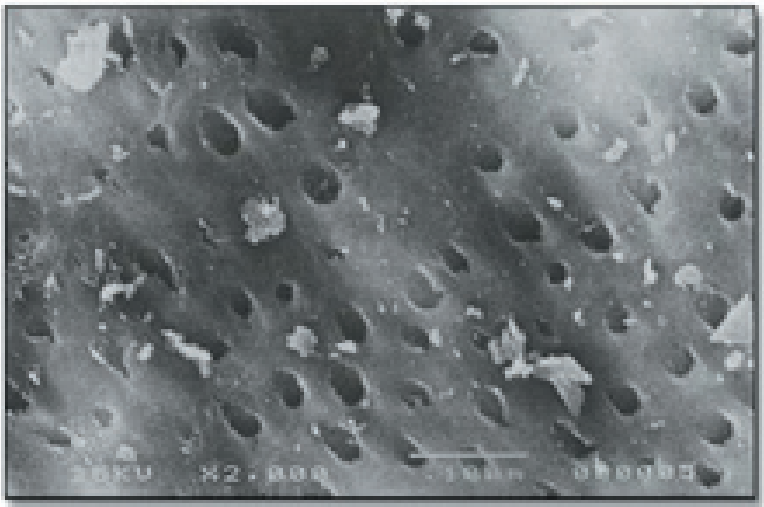

Figure 10: SEM photemicrograph of dentin surface shews grinding debtis, opened dentinal tubules, and dentinal tubules partially occluded. Healthy etched and miswak

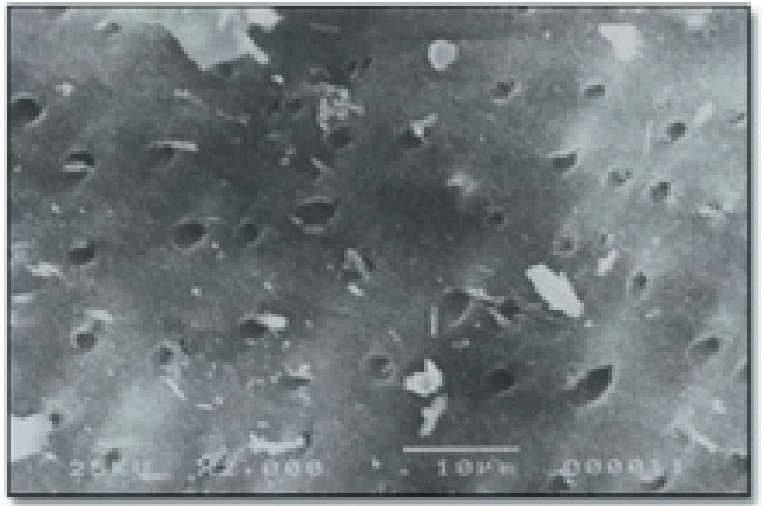

Figure 11: SEM photomicrograph of dentin surface shows grinding debris, partially opened dentinal tubules, and opened dentinai tubules. Periedontally involved etched and miswaki 


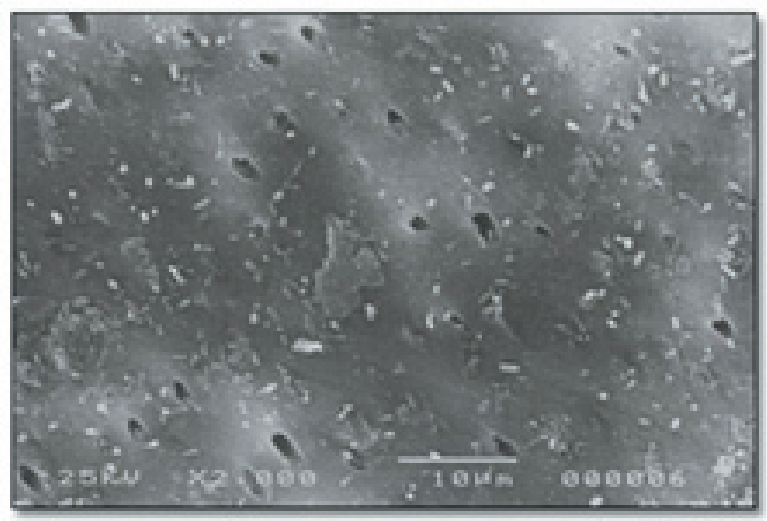

Figure 12: SEM photemierograph of dentin surface shows grinding debris, partially opened destinal tubules, and opened demtinal tubules. (Healthy unetched and miswak)

\section{Discussion}

This study investigated utilizing a SEM examination of root dentin after application of $\mathrm{CHX}$ and miswak extract. The root dentin was either etched or unetched by using citric acid on both healthy and periodontally involved surfaces.

A root surface exposed to a periodontal pocket may harbor bacterial cells $\mathrm{s}^{22,23}$ as well as their cytotoxic products ${ }^{24,25}$, thus, representing a poor substrate for plasma protein absorption and subsequent fibrin adhesion. The root surface may then become hypermineralized and may accumulate exogenous organic material. ${ }^{25}$ Chemical decontamination or detoxification of diseased root surfaces has been achieved with agents such as EDTA $^{26}$, tetracycline hydrochloride ${ }^{27}$, and citric acid. $^{28}$ Etching agents dissolve the smear layer as well as parts of the mineralized root surface exposing collagenous fibers depending on exposure time and agent. ${ }^{28}$ However, conflicting results regarding the etching effect have been presented depending on the mode of application. ${ }^{29}$ Rubbing of the dentin surface with a cotton pellet soaked in citric acid appears to expose more intertubular fibrils and widen dentinal tubules to a greater extent compared to passive application (without rubbing) of the acid. ${ }^{30}$ In the present study, the passive application of citric acid was performed to avoid the mechanical action of rubbing the dentin and creating a smear layer. After mechanical instrumentation of a root surface, a smear layer is usually present. ${ }^{31}$ It has been characterized as an amorphous structure obscuring the underlying dentin surface. ${ }^{31}$ After acid treatment, the smear layer is removed leaving patent dentinal tubules and varying degrees of dentin matrix exposed. ${ }^{32,33}$
The results of the present study suggest the agents used for conditioning root surfaces affect the surfaces in different ways and may be of importance in periodontal regenerative procedures. Wen et $\mathrm{al}^{30}$ evaluated the effect of citric acid $(\mathrm{pH}$ 1.0) application techniques on freshly extracted teeth and concluded it may be undesirable to apply citric acid using excessive pressure. So in the present study the soaking of dentin was done only in etched healthy dentin and when there was a periodontally involved smear layer and grinding debris was present. Etching did partially remove the smear layer in the control group. When $\mathrm{CHX}$ and miswak extract were used, there was less removal of the smear layer in etched dentin by $\mathrm{CHX}$ compared to miswak extract. This may be explained by the possible astringent effect of $\mathrm{CHX}$, though the $\mathrm{pH}$ of both $\mathrm{CHX}$ and miswak extract was similar (6 and 6.1, respectively) in healthy dentin. It was observed that miswak opened more dentinal tubules in periodontally involved dentin as compared to $\mathrm{CHX}$. This may have a clinical implication of enhancing the regenerative opportunity of periodontium and root surface healing.

The clinical interest and relevance of miswak appears to arise from a number of mechanisms in addition to its acidic and antimicrobial properties. The results of the study are limited to physical findings of root dentin changes and do not represent in vivo differences that may result from physiologic effects of miswak extract. The results of the present study are in accordance with previous work regarding the effects of chewing stick extract on healthy and periodontally involved denti ${ }^{34}$ and on healthy dentin. ${ }^{35}$ The chemical analysis of Salvadora persica has shown it contains trimethylamine, salvadorine, chlorides, fluoride in large amounts, silica, sulphur, vitamin C, and small quantitites of tannins, saponins, flavenoids, and sterols. ${ }^{36}$ It would be interesting to find out the effect of these individual constituents of miswak on root dentin.

The surface characteristics produced by the two solutions ( $\mathrm{CHX}$ and miswak) were not significantly different, so the selection of either agent should be based on its other properties. Additional studies in the future may provide results that could justify the clinical application of these agents. The role of both $\mathrm{CHX}$ and miswak extract may be explored in subjects with dentinal hypersensitivity. 


\section{Conclusions}

Within the limitations of this study, the following conclusions can be drawn:

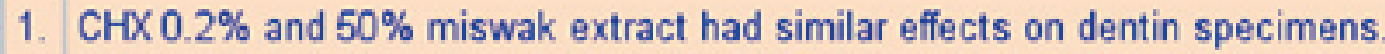

2. Miswak extract removes more smear layer as compared to $\mathrm{CHX}$

3. The $\mathrm{pH}$ of both $\mathrm{CHX}$ and miswak extract may have the same effect on dentin.

4. Further research is needed in vivo to compare the effects of $\mathrm{CHX}$ and miswak extract on periodontally imvolved teeth and hypersensitivity teeth.

\section{References}

Note: Links to citations open in a new browser window. To return to this page, just close the newly opened browser window by clicking on the $\mathrm{X}$ in the upper right hand corner of the window.

1. Almas K. Miswak (chewing stick) and its role in oral health. Postgraduate Dentist Middle East 1993;3(4):214-18.

2. Lewis WW, Lewis ME. Medical Botany. Willy Inter Science Publication, London 1977.

3. Al-Sadhan, Almas K. Miswak (chewing stick): A cultural and scientific heritage. Saudi Dental Journal 1999 May - Aug;11(2):80-87.

4. Almas K, Al-Lafi T. The natural toothbrush. World Health Forum. 1995;16(2):206-10. No abstract available.

5. Al-Lafi T, Ababneh $\mathrm{H}$. The effect of the extract of the miswak (chewing sticks) used in Jordan and the Middle East on oral bacteria. Int Dent J. 1995 Jun;45(3):218-22.

6. Buadu CY, Bokaye Yodem AE. The antibacterial activity of some Ghanian chewing sticks. Ghana Pharmacological J 1973;1:150-53.

7. Rotimi VO, Mosadomi HA. The effect of crude extracts of nine African chewing sticks on oral anaerobes. J Med Microbiol. 1987 Feb;23(1):55-60.

8. Al-Bagieh $\mathrm{NH}$, Almas $\mathrm{K}$. In vitro antimicrobial effects of aqueous and alcohol extracts of miswak (chewing sticks). Cairo Dental Journal 1997;13(2):221-24.

9. Almas $\mathrm{K}, \mathrm{Al}$-Bagieh $\mathrm{NH}$, Akpata ES. In vitro antimicrobial effects of extracts of freshly cut and 1 month old miswak (chewing sticks). Biomedical Letter 1997;56(2):145-49.

10. Almas K. The effect of storage condition on the antimicrobial properties of miswak (Salvadora persica) used in Saudi Arabia. Egyptian Dental Journal 1999 October;45(4):4845-48.

11. Almas K, Stakiw JE. The effect of miswak extract from Salvadora persica stored for 18 years on microbes in vitro. Egyptian Dental Journal 2000 Jan;46(1):227-30.

12. Enwonwu CO, Anyanwu RC. The chewing stick in oral health care. World Health Forum 1985;6:32334.

13. Eid MA, Al-Shammery AR, Selim HA. The relationship between chewing stick (miswak) and periodontal health II. Relationship to plaque, gingivitis, pocket depth and attachment loss. Quintessence Int 1990 Dec; 21(12):1019-22.

14. Almas $\mathrm{K}, \mathrm{Al}-\mathrm{Bahair} \mathrm{K}, \mathrm{Al}-\mathrm{Ragabah} \mathrm{A}$. A comparative pilot study of oral health status among toothbrush and miswak users. Pakistan Oral \& Dental Journal 2000 Jan; 20(1):35-45.

15. Gomes DC, Shakum ML, Ripa LW. Effect of rinsing with $1.5 \%$ hydrogenperoxide (Peroxyl) on gingivitis and plaque. Clin Prev Dent. 1984 May-Jun;6(3):21-5. No abstract available.

16. Grossman E, Reiter G, Sturzenberger OP, et al. Six month study on the effect of a chlorhexidine mouth rinse on gingivitis in adults. J Periodont Res 1986;21 (Suppl):33-39.

17. Segreto VA, Collins EM, Beiswanger BB, et al. A comparison of mouth rinses containing two concentrations of chlorhexidine. J Clin Periodontol. 1992 Mar;19(3):202-7. 
18. Brecx M, Brownstone E, MacDonald L, et al. Efficacy of ListerineÒ and chlorhexidine mouth rinses as supplements to regular tooth-cleaning measures. J Clin Periodontal 1992 March;19(3):202-207.

19. Gjermo P. Chlorhexidine and related compounds. J Dent Res 1989;68 (Spec issue):1602-1608.

20. Wolff CF, Pihlstrom BL, Bakdash ME, et al. Four-year investigation of salt and peroxide regimen compared with conventional oral hygiene. J Am Dent Assoc. 1989 Aug;119(2):283-9.

21. Ciancio SG. Chemical agents: plaque control, calculus reduction and treatment of dentinal hypersensitivity. Periodontol 2000. 1995 Jun;8:75-86. Review. No abstract available.

22. Daly CG, Symour GJ, Kieser JB, et al. Assessment of periodontally involved cementum. J Clin Periodontol. 1982 May;9(3):266-74.

23. Adriaens PA, Edwards CA, De Boever JA, et al. Ultrastructural observations of bacterial invation in cementum and radicular dentin of periodontally diseased human teeth. J Periodontol. 1988 Aug;59(8):493-503.

24. Aleo JJ, De Renzis FA, Farber PA, et al. The presence and biological activity of cementum bond endotoxin. J Periodontol. 1974 Sep;45(9):672-5. No abstract available.

25. Aleo JJ, De Renzis FA, Farber PA. In vitro attachment of human gingival fibroblasts to root surfaces. J Periodontol 1975;46:639-645.

26. Blomlof J, Jansson L, Blomlof L, et al. Root surface etching at neutral pH promotes periodontal healing. J Clin Periodontol. 1996 Jan;23(1):50-5.

27. Terranova VP, Franzetti LC, Hic S, et al. A biomechanical approach to periodontal regeneration. Tetracycline treatment of dentin promotes fibroblast adhesion and growth. J Periodontal Res. 1986 Jul;21(4):330-7. No abstract available.

28. Lasho DJ, O'Leary TJ, Kafrawy AW. A scanning electron microscope study of the effect of various agents on instrumented periodontally involved root surfaces. J Periodontol. 1983 Apr;54(4):210-20.

29. Sterrett JD, Dhillon M, Murphy HJ. Citric acid demineralization of cementum and dentin: the effect of application pressure. J Clin Periodontol. 1995 Jun;22(6):434-41.

30. Wen CR, Caffesse RG, Morrisson EC, et al. In vitro effects of citric acid application techniques on dentin surface. J Periodontol. 1992 Nov;63(11):883-9.

31. Jones SJ, Lozdan J, Boyde A. Tooth surfaces treated in situ with periodontal instruments. SEM studies. Brit Dent J 1972 Jan 18;132(2):57-64. No abstract available.

32. Polson AM, Frederick GT, Ladenheim S, et al. The production of a root surface smear layer by instrumentation and its removal by citric acid. J Periodontol. 1984 Aug;55(8):443-6.

33. Brannstrom M, Johnson $\mathrm{G}$. Effects of various conditioners and cleaning agents on prepared dentin surface: A scanning electron microscopic investigation. J Prosthet Dent. 1974 Apr;31(4):422-30. No abstract available.

34. Almas K. The effect of extract of chewing sticks (Salvadora persica) on healthy and periodontally involved human dentin: A SEM study. Indian J Dent Res. 2001 Jul-Sep;12(3):127-32.

35. Babay N, Almas K. Effect of miswak extract on healthy human dentin: An in vitro study. Saudi Dent J 1999May - August;11(2):46-52.

36. Akhtar MS, Ajmal M. Significance of chewing sticks (miswaks) in oral hygiene from a pharmacological viewpoint. J Pak Med Assoc. 1981 Apr;31(4):89-95. No abstract available.

(The study has been presented as an oral presentation at the 11th Saudi International Dental Meeting, 28th February - 2nd March 2000, Riyadh, Saudi Arabia.) 
About the Author

Khalid Almas, BDS, MSE, DDPH, FRACDS, FDSRCS, FICD, FADI

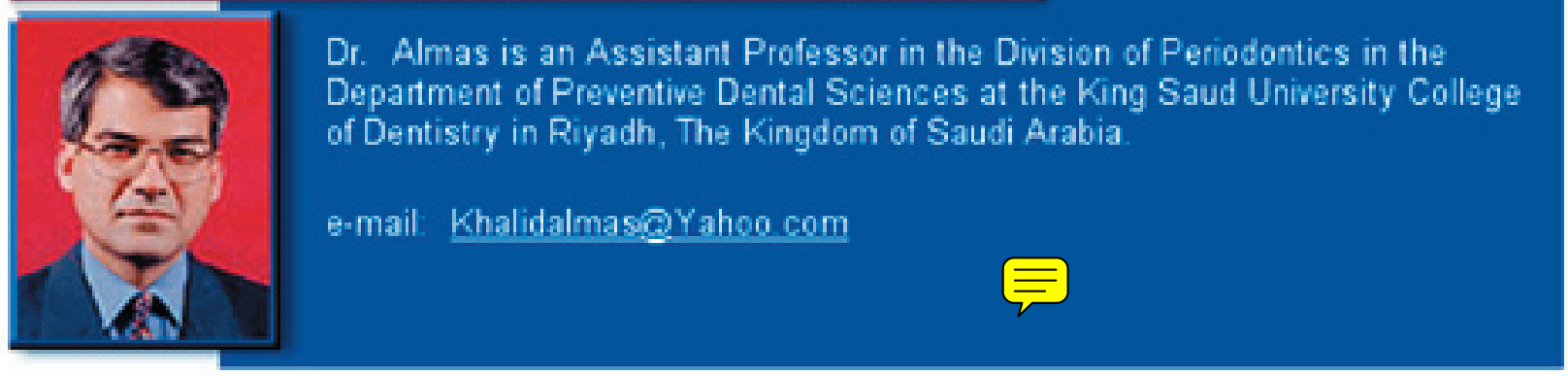

